\title{
Development of new Fe-Al-Nb(-B) alloys for structural applications at high temperatures
}

\author{
Angelika Gedsun ${ }^{1}\left[\right.$ ] Frank Stein ${ }^{1} \cdot$ Martin Palm ${ }^{1}$
}

Received: 16 December 2020 / Accepted: 18 March 2021 / Published online: 31 March 2021

(c) The Author(s) 2021

\begin{abstract}
It is known for $\mathrm{Fe}-\mathrm{Al}-\mathrm{Ta}$ alloys, that a homogeneous distribution of strengthening Laves phase precipitates in the matrix and aligned at the grain boundaries can be obtained when the formation of the stable Laves phase is preceded by the formation of the metastable Heusler phase. Several $\mathrm{Fe}-\mathrm{Al}-\mathrm{Nb}$ alloys with different $\mathrm{Al}$ and $\mathrm{Nb}$ contents and with or without boron doping are studied to elucidate whether comparable microstructures can be obtained in this system. It was found that the Heusler phase only occurs within a limited composition range. The time-dependent evolution of the microstructure shows that the transformation proceeds faster in $\mathrm{Fe}-\mathrm{Al}-\mathrm{Nb}$ alloys. Microhardness was measured in dependence on the microstructural evolution with increasing annealing time, and compressive yield stress was determined for alloys annealed $700{ }^{\circ} \mathrm{C} / 1000 \mathrm{~h}$ to evaluate the influence of microstructure and composition.
\end{abstract}

\section{Introduction}

Due to their outstanding wear and corrosion resistance, iron aluminides are considered for structural applications at high temperatures [1]. Because of their low density and good mechanical properties at moderate temperatures, they are particularly interesting for energy-saving components, specifically for moving parts such as turbine blades. However, high temperature mechanical properties, such as yield stress and creep resistance are still not sufficient for wider industrial application. Through different alloying concepts, e.g. strengthening coherent or incoherent second phases such as borides or Laves phase precipitates, the mechanical properties of iron aluminides can be further enhanced at higher temperatures $[2,3]$. In many $\mathrm{Fe}-\mathrm{Al}-\mathrm{X}$ systems the Laves phase forms directly from the melt and solidifies as coarse dendrites $[4,5]$. In this case, the distribution of the Laves phase cannot be controlled, and rather brittle alloys are obtained [5]. It has been shown recently, that a controlled homogeneous distribution of Laves phase can be achieved in $\mathrm{Fe}-\mathrm{Al}-\mathrm{Ta}$ alloys, where the formation of the stable hexagonal C14 Laves phase is kinetically retarded. Instead of the Laves phase, coherent precipitates of metastable L2 ${ }_{1}$ Heusler

Angelika Gedsun

a.gedsun@mpie.de

1 Max-Planck-Institut für Eisenforschung GmbH, Düsseldorf, Germany phase form when the $\mathrm{Fe}-\mathrm{Al}$ matrix becomes supersaturated with Ta on cooling. The transformation from the metastable Heusler phase to the stable Laves phase can be controlled through the choice of heat treatment, thermomechanical processing or doping the alloy with boron. Thereby different microstructures with fine-scaled and homogeneously distributed Laves phase precipitates inside the $\mathrm{Fe}-\mathrm{Al}$ matrix or at grain boundaries can be obtained [3]. Previous research shows that the $\mathrm{Fe}-\mathrm{Al}-\mathrm{Nb}$ system is the only other system, where the formation of the stable Laves phase is preceded by the formation of the metastable Heusler phase [6, 7]. The present research continues the work on the influence of boron on the microstructure and the mechanical properties in $\mathrm{Fe}-\mathrm{Al}-\mathrm{Nb}$ alloys [8]. It is part of a larger project, which aims at clarifying whether mechanisms, which enable a microstructural design - and thereby tailoring of mechanical properties-in $\mathrm{Fe}-\mathrm{Al}-\mathrm{Ta}$ alloys, can also be realized in case of $\mathrm{Fe}-\mathrm{Al}-\mathrm{Nb}$. As the properties of the $\mathrm{Fe}-\mathrm{Al}-\mathrm{Ta}$ alloys are considered as attractive by industries, $\mathrm{Fe}-\mathrm{Al}-\mathrm{Nb}$ alloys with comparable properties would be a slightly more light-weight, but specifically more economically efficient, alternative.

Therefore, the composition range where the Heusler phase may form and the transformation kinetics from metastable Heusler phase to stable Laves phase are studied. Microstructures are characterized by metallography, crystallographic structures and compositions of the stable phases were determined. A preliminary evaluation of the resulting 
mechanical properties has been performed by microhardness and compression tests.

\section{Experimental}

Alloys of five different compositions, with $\mathrm{Al}$ contents between 25 and 34 at.\% and 2-3 at.\% Nb, partially doped with boron $(<100 \mathrm{ppm})$, were produced by vacuum induction melting from $\mathrm{Fe}$ ( 99.9 wt.\%), $\mathrm{Al}$ (99.9 wt.\%), Nb (99.9 wt.\%) and B (99.4 wt.\%) under argon and cast into copper molds of $20 \mathrm{~mm}$ diameter. Compositions were selected on the basis of the existing phase diagrams $[9,10]$ in a way that a sufficient supersaturation of the $\mathrm{Fe}-\mathrm{Al}$ matrix is attained on cooling and that the alloys contain at least 5 vol. $\%$ of precipitates at $700{ }^{\circ} \mathrm{C}$, which is a possible application temperature. Because boron doping facilitated the transformation from Heusler to Laves phase in $\mathrm{Fe}-\mathrm{Al}-\mathrm{Ta}$ alloys, three alloys were doped with boron. The actual alloy compositions were determined by wet chemical analysis. Heat treatments were performed at $700{ }^{\circ} \mathrm{C}$ for $1 \mathrm{~h}, 10 \mathrm{~h}, 100 \mathrm{~h}$ and $1000 \mathrm{~h}$ in order to evaluate the microstructural evolution and kinetics of the transformation from metastable $\mathrm{L} 2{ }_{1}$ Heusler phase to the stable C14 Laves phase. Metallographic sections were prepared by grinding and polishing the alloys, the last step being polishing with a $0.5 \mu \mathrm{m}$-particles diamond suspension. Additional preparation with an oxide polishing suspension (OPS) for a few seconds was only used in some cases.

The microstructure of the alloys in the as-cast condition and after heat treatment was inspected by light optical and scanning electron microscopy (SEM: LEO 1550 VP, Zeiss). Phases were characterized by X-ray diffraction (XRD: Bruker D8 Advance A25) on metallographic sections by scanning the $2 \theta$ range from $20^{\circ}$ to $125^{\circ}$ using Co-Karadiation $(\lambda=0.1709 \mathrm{~nm})$. The chemical compositions of the phases were established by wavelength-dispersive electron probe microanalysis (EPMA: Jeol JXA-8100).

For mechanical testing at higher temperatures cuboidal shaped samples with dimensions $10 \times 5 \times 5 \mathrm{~mm}^{3}$ were cut by electrical discharge machining (EDM), while for tests at room temperature and at $200{ }^{\circ} \mathrm{C}$ cylindrical samples of
$10 \mathrm{~mm}$ height and $5 \mathrm{~mm}$ diameter were employed, which, in contrast to the rectangular samples, showed no shearing at these low temperatures. Compression tests were performed at a deformation rate of $10^{-4} \mathrm{~s}^{-1}$ between room temperature and $800{ }^{\circ} \mathrm{C}$ (ZwickRoell Z100). The microhardness was established by Vickers indents with $0.0098 \mathrm{~N}$.

\section{Results and discussion}

\section{Microstructural observations}

Nominal and actual compositions of the alloys are shown in Table 1 . Systematically lower amounts of $\mathrm{Al}$ and slightly higher amounts of $\mathrm{B}$ are observed. The lower amounts of $\mathrm{Al}$ may be explained by preferential evaporation of $\mathrm{Al}$ during the induction melting. The increased $\mathrm{B}$ contents reflect the difficulty of precisely adjusting such low alloying contents, though the actual deviation should not exceed the effect of doping the alloys. Compositions of phases as determined by EPMA after heat treatment of the alloys at $700{ }^{\circ} \mathrm{C}$ for $1000 \mathrm{~h}$ are also shown in Table 1 . The crystallographic structures of the phases for all alloys after $700{ }^{\circ} \mathrm{C} / 1000 \mathrm{~h}$, as determined via XRD, are $\mathrm{DO}_{3}$ for the $\mathrm{Fe}_{3} \mathrm{Al}$ matrix and $\mathrm{C} 14$ for the Laves phase. Though, at $700{ }^{\circ} \mathrm{C}$ the $\mathrm{Fe}-\mathrm{Al}$ matrix is actually B2-ordered for all compositions, but it transforms to $\mathrm{DO}_{3}$ during cooling to room temperature [6]. As an example the diffractogram of alloy Fe-24.4Al-2Nb-0.03B annealed $700{ }^{\circ} \mathrm{C} / 1000 \mathrm{~h}$ is shown in Fig. 1. In the boron-doped alloys, no boride precipitates were observed by XRD, SEM or EMPA.

The microstructures of all alloys in the as-cast condition and after annealing for various times at $700{ }^{\circ} \mathrm{C}$ are shown in Figs. 2, 3, 4. The grains are globular with a grain size $>50 \mu \mathrm{m}$ in the middle of the alloys, while at the edges elongated grains of about $150 \mu \mathrm{m}$ length are observed. The latter started solidifying at the cold crucible wall. No larger pores were observed in any of the investigated alloys. For the alloys with about 32 and 34 at.\% $\mathrm{Al}$, the grain boundaries are almost completely covered by a second phase already in the as-cast condition (Fig. 2).

Table 1 Actual compositions of the alloys, determined by wet-chemical analysis and compositions of the phases, determined by EPMA after heat treatment $700{ }^{\circ} \mathrm{C} / 1000 \mathrm{~h}$

\begin{tabular}{|c|c|c|c|c|c|c|c|}
\hline \multirow[t]{2}{*}{ Nominal composition } & \multirow[t]{2}{*}{ Actual composition } & \multicolumn{3}{|c|}{$\mathrm{Fe}_{3} \mathrm{Al}$ matrix } & \multicolumn{3}{|c|}{ C14 Laves phase } \\
\hline & & at. $\% \mathrm{Fe}$ & at. $\% \mathrm{Al}$ & at. $\% \mathrm{Nb}$ & at. $\% \mathrm{Fe}$ & at. $\% \mathrm{Al}$ & at. $\% \mathrm{Nb}$ \\
\hline $\mathrm{Fe}-25 \mathrm{Al}-2 \mathrm{Nb}-0.01 \mathrm{~B}$ & $\mathrm{Fe}-24.4 \mathrm{Al}-2 \mathrm{Nb}-0.03 \mathrm{~B}$ & $74.4 \pm 0.7$ & $25.2 \pm 0.6$ & $0.4 \pm 0.1$ & $59.7 \pm 1.3$ & $17.0 \pm 0.6$ & $23.3 \pm 1.7$ \\
\hline $\mathrm{Fe}-32 \mathrm{Al}-3 \mathrm{Nb}$ & $\mathrm{Fe}-31.9 \mathrm{Al}-3 \mathrm{Nb}$ & $66.2 \pm 0.2$ & $32.0 \pm 0.3$ & $1.8 \pm 0.2$ & $52.5 \pm 1.0$ & $21.9 \pm 1.2$ & $25.6 \pm 0.6$ \\
\hline $\mathrm{Fe}-32 \mathrm{Al}-3 \mathrm{Nb}-0.01 \mathrm{~B}$ & $\mathrm{Fe}-31 \mathrm{Al}-3 \mathrm{Nb}-0.06 \mathrm{~B}$ & $65.6 \pm 0.3$ & $32.5 \pm 0.3$ & $1.9 \pm 0.2$ & $52.7 \pm 1.0$ & $22.1 \pm 0.6$ & $25.2 \pm 0.7$ \\
\hline $\mathrm{Fe}-34 \mathrm{Al}-3 \mathrm{Nb}$ & $\mathrm{Fe}-33.6 \mathrm{Al}-3 \mathrm{Nb}$ & $64.2 \pm 0.6$ & $33.6 \pm 0.4$ & $2.2 \pm 0.2$ & $52.0 \pm 0.9$ & $23.1 \pm 0.6$ & $24.9 \pm 0.7$ \\
\hline $\mathrm{Fe}-34 \mathrm{Al}-3 \mathrm{Nb}-0.01 \mathrm{~B}$ & $\mathrm{Fe}-33.6 \mathrm{Al}-3 \mathrm{Nb}-0.03 \mathrm{~B}$ & $63.1 \pm 0.4$ & $34.4 \pm 0.1$ & $2.5 \pm 0.3$ & $51.5 \pm 1.5$ & $23.5 \pm 0.6$ & $25.0 \pm 1.8$ \\
\hline
\end{tabular}




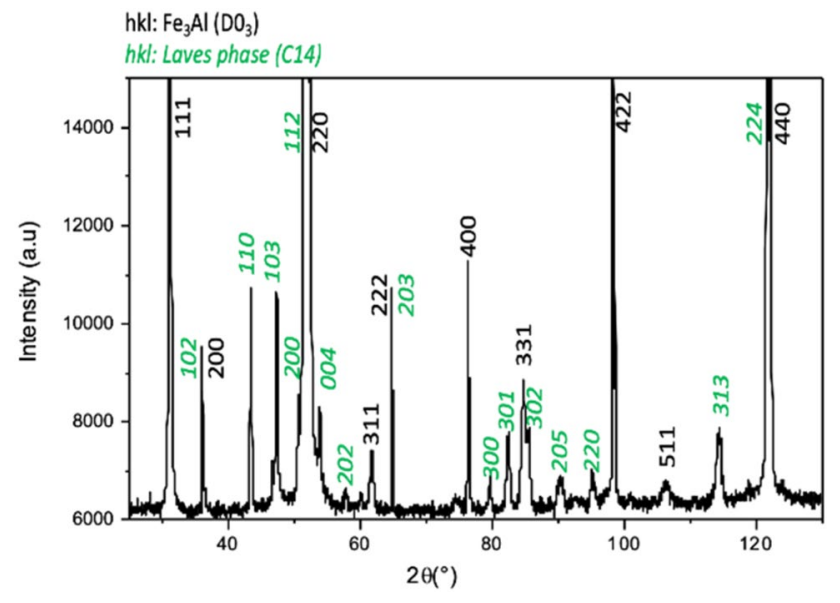

Fig. 1 XRD diffractogram of the alloy $\mathrm{Fe}-24.4 \mathrm{Al}-2 \mathrm{Nb}-0.03 \mathrm{~B}$ annealed $700{ }^{\circ} \mathrm{C} / 1000 \mathrm{~h}$

These particles have an elongated, needle- or plate-like shape and are about $3 \mu \mathrm{m}$ long (see Fig. 4d). According to their composition determined by EPMA, these particles are the Laves phase. The Laves phase apparently solidified during cooling as $\mathrm{Fe}-\mathrm{Al}+$ Laves phase eutectic, which is clearly discernible at higher magnification at triple points of the grain boundaries (Fig. 2a). In contrast to the more Al-rich alloys, Fe-24.4Al-2Nb-0.03B shows only very few precipitates at the grain boundaries (Fig. 2d).
Figure 3 shows the microstructures after heat treatment at $700{ }^{\circ} \mathrm{C} / 1000 \mathrm{~h}$. From previous investigations, it can be assumed that after this time the alloys are in equilibrium at $700{ }^{\circ} \mathrm{C}$ [9]. Compared to the as-cast state, there is little change in the microstructures of the alloys with about 32 and 34 at.\% after this heat treatment. The Laves phase has coarsened at the grain boundaries and few new Laves phase precipitates have formed within the $\mathrm{Fe}-\mathrm{Al}$ grains. In contrast, $\mathrm{Fe}-24.4 \mathrm{Al}-2 \mathrm{Nb}-0.03 \mathrm{~B}$ shows a remarkable microstructural development. After $700{ }^{\circ} \mathrm{C} / 1000 \mathrm{~h}$ it shows a microstructure with an evenly distribution of Laves phase particles in the matrix and at grain boundaries (Fig. 3c). In order to understand the differences in the microstructures after $700{ }^{\circ} \mathrm{C} / 1000 \mathrm{~h}$, the observations of the microstructural development with increasing annealing time is very helpful (Fig. 4). In the as-cast condition there are few Laves phase precipitates at the grain boundaries (Fig. 4a) and an indication of some kind of "structuring" is visible in the $\mathrm{Fe}-\mathrm{Al}$ matrix. Already after $1 \mathrm{~h}$ annealing at $700{ }^{\circ} \mathrm{C}$ (Fig. 4b), the amount of Laves phase at the grain boundaries has markedly increased and the "structuring" in the $\mathrm{Fe}-\mathrm{Al}$ matrix now has the typical appearance, known for the coherent precipitation of fine Heusler phase particles [3]. Moreover, there is a zone along the grain boundaries, where the Laves phase precipitates grew, without any Heusler phase precipitates. Such a precipitation free zone (PFZ) is typical for the formation of the stable Laves phase at the grain boundaries by dissolution of the
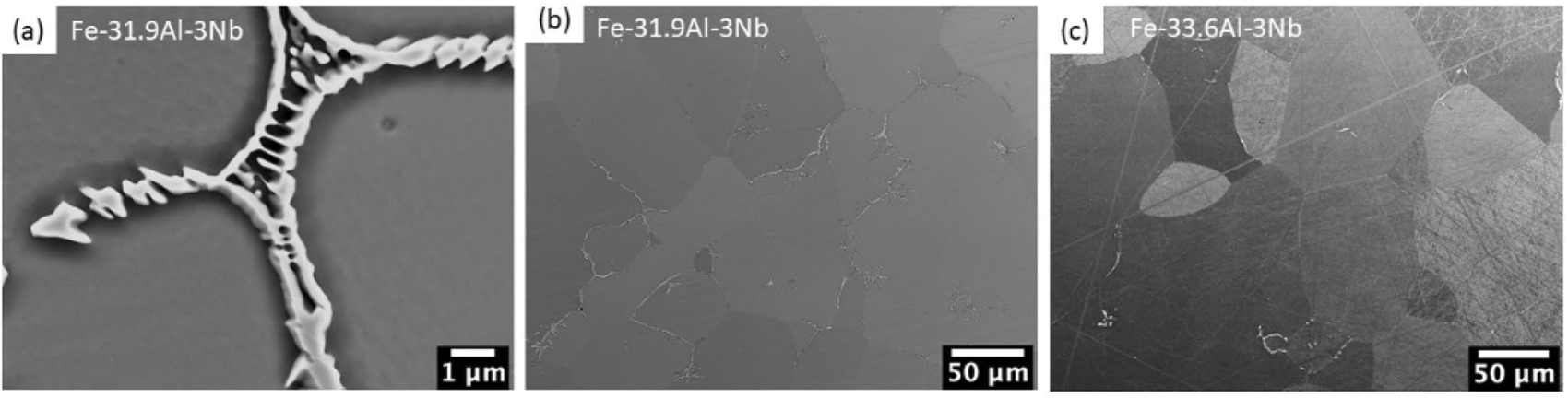

(d) Fe-24.4Al-2Nb-0.03B

(e) $\mathrm{Fe}-31 \mathrm{Al}-3 \mathrm{Nb}-0.06 \mathrm{~B}$

(f) $\mathrm{Fe}-33,6 \mathrm{Al}-3 \mathrm{Nb}-0.03 \mathrm{~B}$
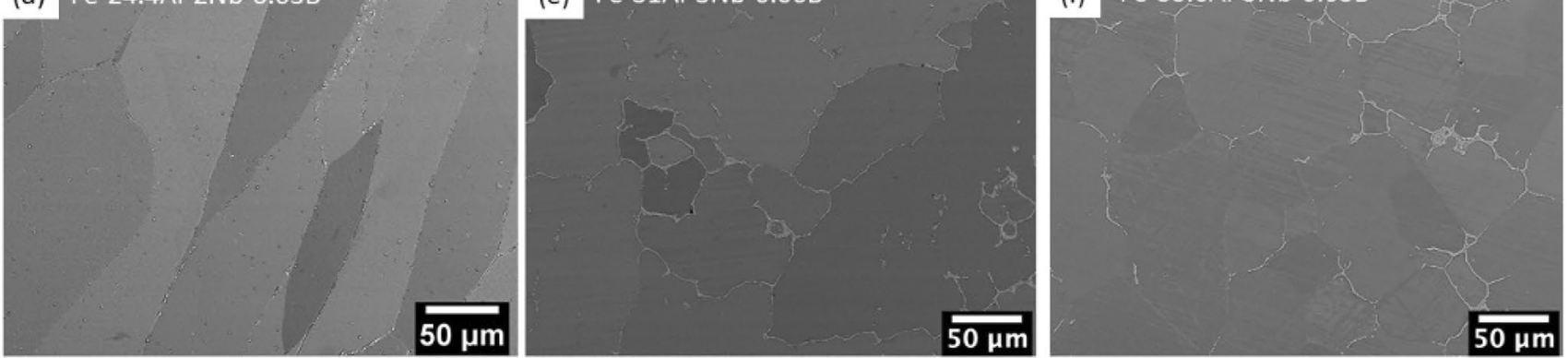

Fig. 2 Back-scattered electron (BSE) micrographs of (a) alloy $\mathrm{Fe}-$ $31.9 \mathrm{Al}-3 \mathrm{Nb}$ in as-cast condition, showing eutectic at grain boundary triple points, $(\mathbf{b}-\mathbf{f})$ alloys with different composition in as-cast condi- tion, showing the microstructural development in dependence on $\mathrm{Al}$ content $(\mathbf{b}, \mathbf{c})$ and the influence of boron $(\mathbf{d}-\mathbf{f})$ 


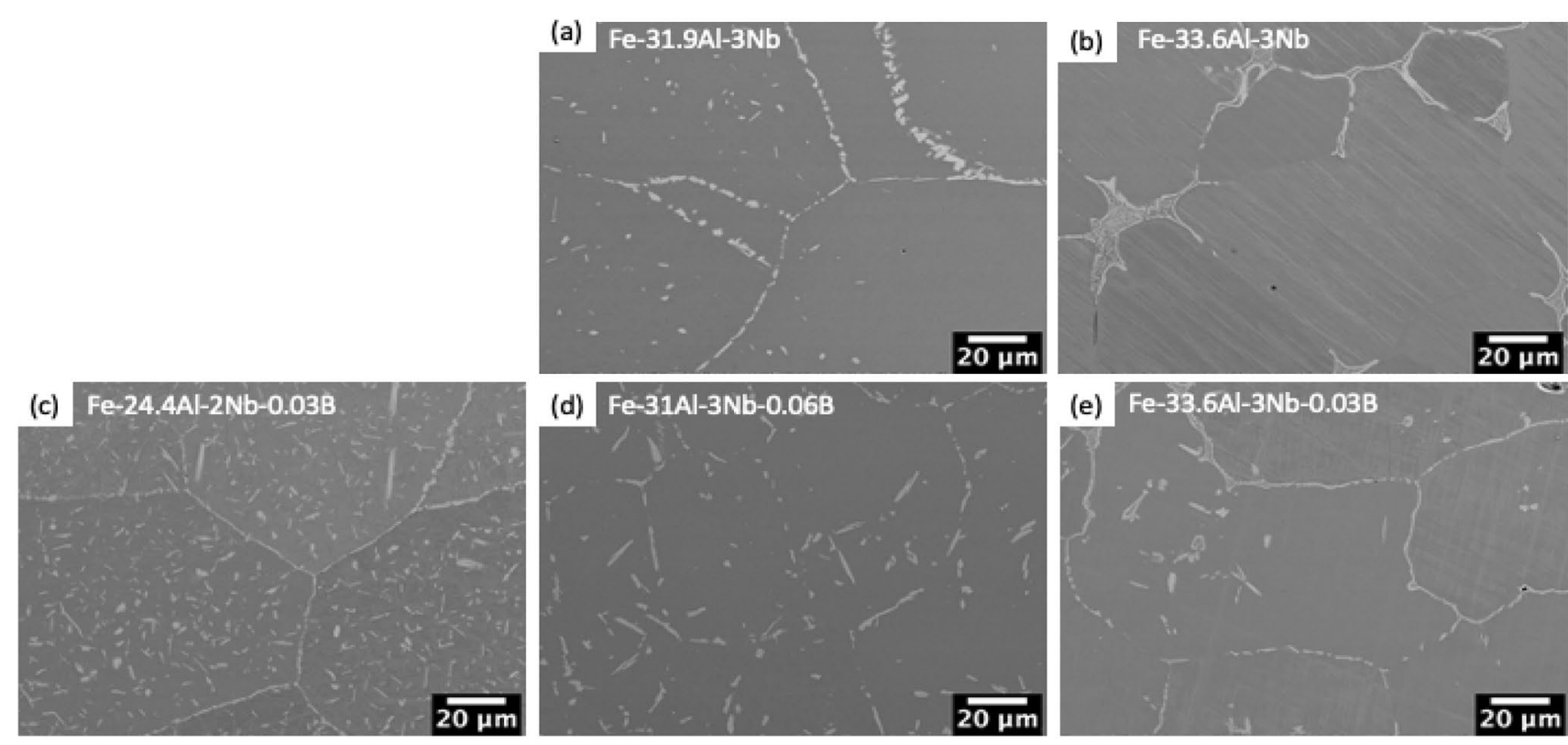

Fig. 3 BSE micrographs of the alloys, shown in Fig. 2 after heat treatment $700{ }^{\circ} \mathrm{C} / 1000 \mathrm{~h}$. By XRD and EPMA the grey matrix has been identified as $\mathrm{D}_{3}$-ordered $\mathrm{Fe}-\mathrm{Al}$ while the light precipitates are Laves phase

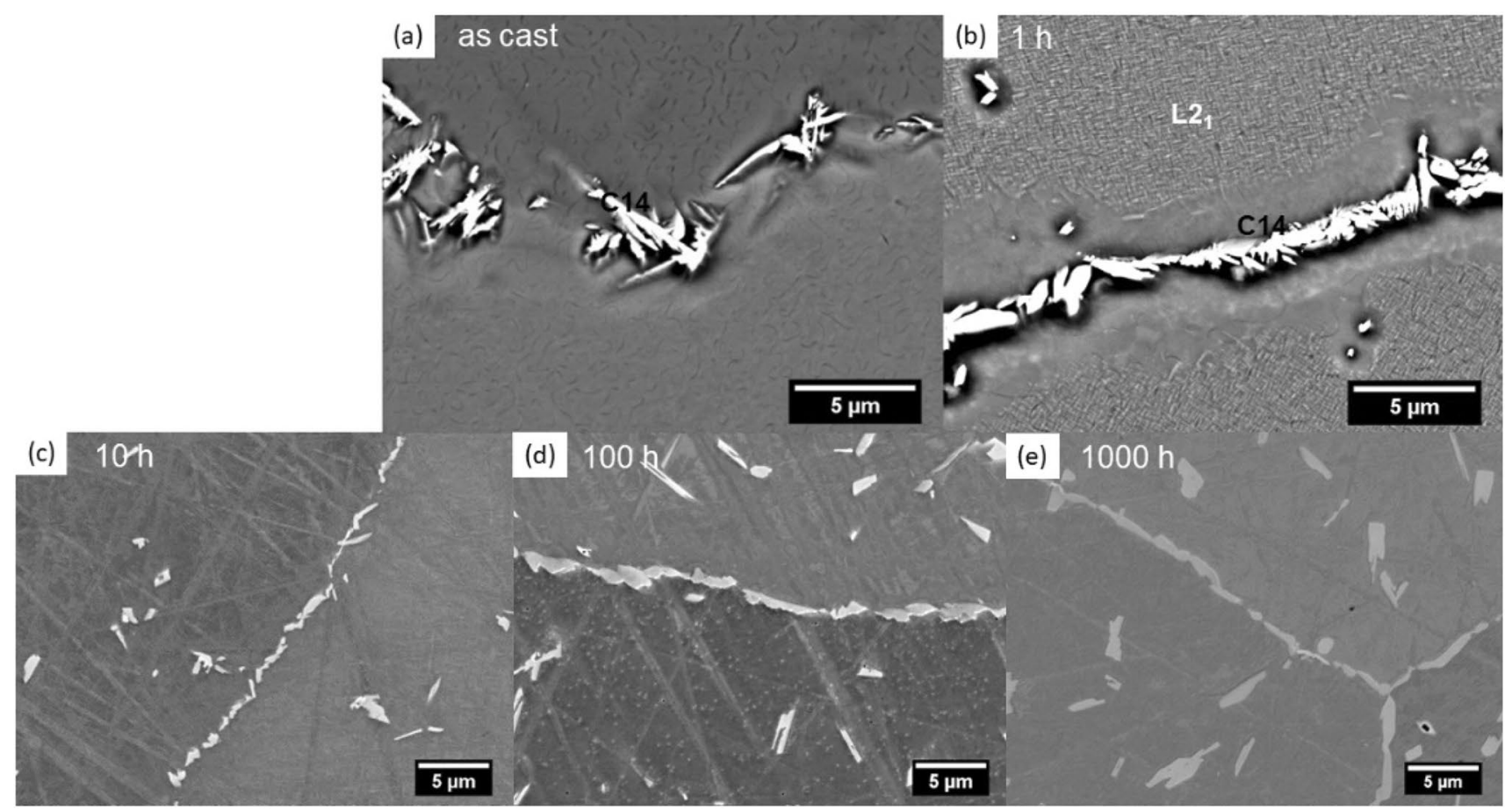

Fig. 4 BSE micrographs of Fe24.4Al-2Nb-0.03B in (a) as-cast condition and after heat treatment at $700{ }^{\circ} \mathrm{C}$ for (b) $1 \mathrm{~h},(\mathbf{c}) 10 \mathrm{~h},(\mathbf{d}) 100 \mathrm{~h}$ and (e) $1000 \mathrm{~h}$

neighboring metastable Heusler phase [3]. After $10 \mathrm{~h}$ no Heusler phase can be observed any longer in the micrographs (Fig. 4c). Instead, some small Laves phase precipitates are found within the $\mathrm{Fe}-\mathrm{Al}$ grains. With prolonged annealing time (Fig. 4d, e), the amount of these small precipitates in the $\mathrm{Fe}-\mathrm{Al}$ grains increases and the Laves phase precipitates at the grain boundaries grow together and form a continuous layer (Fig. 4e). 


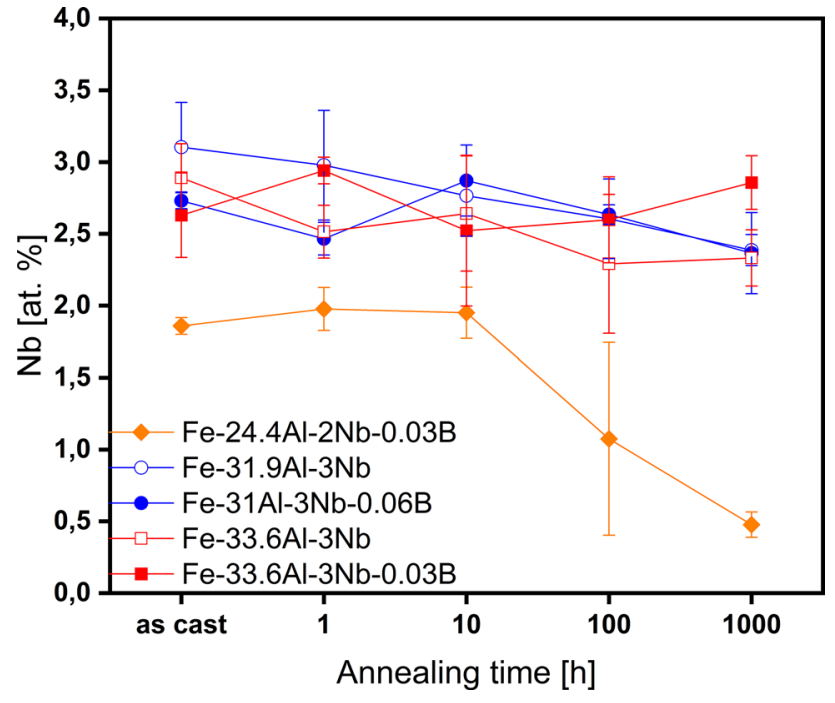

Fig. $5 \mathrm{Nb}$ content of the $\mathrm{Fe}-\mathrm{Al}$ matrix in dependence on annealing time as determined by EPMA

The microstructural evolution in Fe-24.4Al-2Nb-0.03B with increasing annealing time is paralleled by the change in the $\mathrm{Nb}$ content in the $\mathrm{Fe}-\mathrm{Al}$ matrix (Fig. 5), as determined by EPMA. Because the Heusler phase precipitates shown in Fig. $4 \mathrm{~b}$ are too fine-scaled to be resolved by EPMA, measurements of the $\mathrm{Fe}-\mathrm{Al}$ matrix after $1 \mathrm{~h}$ annealing are actually for $\mathrm{Fe}-\mathrm{Al}+$ Heusler phase. The data in Fig. 5 show a significant decrease of the $\mathrm{Nb}$ content after $100 \mathrm{~h}$ at $700{ }^{\circ} \mathrm{C}$. This should indicate that after $10 \mathrm{~h}$ there is still a marked amount of Heusler phase present in the matrix, though it is not any longer visible in the micrograph (Fig. 4c). However, as the Heusler phase is so fine-scaled, only ongoing transmission electron microscopy (TEM) will be able to clarify this. Actually, the presence of coherent Heusler phase precipitates in $\mathrm{Fe}-25 \mathrm{Al}-2 \mathrm{Nb}$ after annealing for $8-10 \mathrm{~h}$ at $700{ }^{\circ} \mathrm{C}$ has been revealed by TEM before [6, 7]. After $1000 \mathrm{~h}$ the $\mathrm{Nb}$ content in the $\mathrm{Fe}-\mathrm{Al}$ matrix has decreased to 0.4 at.\% (Table 1), which is about the value that has been previously reported for the solubility in Fe-25 Al [7] and which is expected in equilibrium [9]. Measurement of the composition of the $\mathrm{Fe}-\mathrm{Al}$ matrix in the alloys with about 32 and 34 at.\% $\mathrm{Al}$ shows that the $\mathrm{Nb}$ content does not decrease with prolonged annealing, revealing that in these alloys the $\mathrm{Fe}-\mathrm{Al}$ matrix was not supersaturated with $\mathrm{Nb}$ at $700{ }^{\circ} \mathrm{C}$. As supersaturation is a prerequisite for the formation of metastable Heusler phase $[3,6,7]$ and thereby for the formation of evenly distributed fine-scaled Laves phase precipitates, it becomes clear why such a microstructure is only obtained in the case of $\mathrm{Fe}-24.4 \mathrm{Al}-2 \mathrm{Nb}-0.03 \mathrm{~B}$, but not for the alloys with higher $\mathrm{Al}$ contents.

The present results also give an indication up to which Al content the metastable Heusler phase may occur in
$\mathrm{Fe}-\mathrm{Al}$ alloys. Only at 24.4 at.\% $\mathrm{Al}$, the Heusler phase is observed while at 31 at.\% $\mathrm{Al}$ and at higher $\mathrm{Al}$ contents it is not observed any longer. Previous studies demonstrated the occurrence of metastable Heusler phase in alloys in the range of 15-30 at.\% $\mathrm{Al}$ [11], which is in line with the present results. At least for the alloys with about 32 and 34 at.\% Al, doping with boron has no significant effect on the microstructure (Fig. 3. The current research continues the work on boron-doped $\mathrm{Fe}-\mathrm{Al}-\mathrm{Nb}$ alloys by Azmi et at.[8]. In that work, a microstructure with evenly distributed Laves phase within the matrix and at the grain boundaries was obtained in an alloy with 25.9 at.\% $\mathrm{Al}, 2.5$ at.\% $\mathrm{Nb}$ and 0.07 at.\% $\mathrm{B}$ after annealing at $700{ }^{\circ} \mathrm{C}$ for $1000 \mathrm{~h}$. The alloy has also been investigated in the as-cast condition and after $100 \mathrm{~h}$ annealing at $700{ }^{\circ} \mathrm{C}$, but no evidence of the Heusler phase was found.

Figure 6 shows the time-temperature-transformation (TTT) diagram for the transformation of the metastable Heusler phase to the stable Laves phase [6, 7]. Additional data for $\mathrm{Fe}-24.4 \mathrm{Al}-2 \mathrm{Nb}-0.03 \mathrm{~B}$ indicate that the transformation in the B-doped alloy proceeds faster at $700{ }^{\circ} \mathrm{C}$ than in the ternary alloys. However, as no data for ternary alloys with annealing times longer than $10 \mathrm{~h}$ exist, this point has to be clarified. Compared to $\mathrm{Fe}-\mathrm{Al}-\mathrm{Ta}$ alloys [3], the transformation (indicated by a dashed line in Fig. 6) occurs earlier at a given temperature for $\mathrm{Fe}-\mathrm{Al}-\mathrm{Nb}(-\mathrm{B})$ alloys.

\section{Mechanical properties}

Figure 7 shows the compressive yield stress $\sigma_{0.2}$ for the $\mathrm{Fe}-\mathrm{Al}-\mathrm{Nb}(-\mathrm{B})$ alloys heat-treated $700{ }^{\circ} \mathrm{C} / 1000 \mathrm{~h}$ in comparison with the boron-doped alloys from [8], a hot-rolled

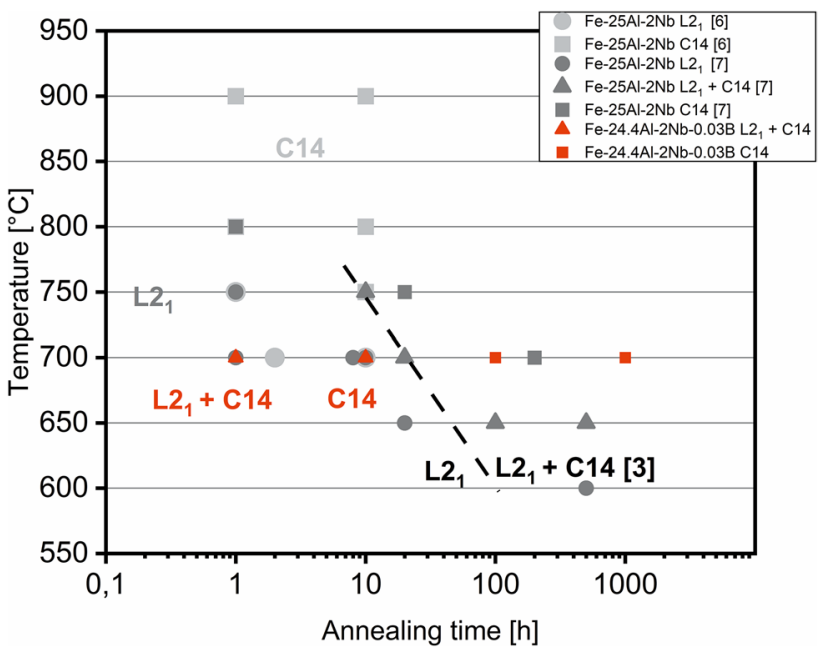

Fig. 6 TTT diagram for the dissolution of the $\mathrm{L} 2{ }_{1}$ Heusler phase and precipitation of the $\mathrm{C} 14$ Laves phase in $\mathrm{Fe}-25 \mathrm{Al}-2 \mathrm{Nb}[6,7]$ and $\mathrm{Fe}-$ $24.4 \mathrm{Al}-2 \mathrm{Nb}-0.03 \mathrm{~B}$ compared with the transformation in $\mathrm{Fe}-\mathrm{Al}-\mathrm{Ta}$ (dashed line) [3] 


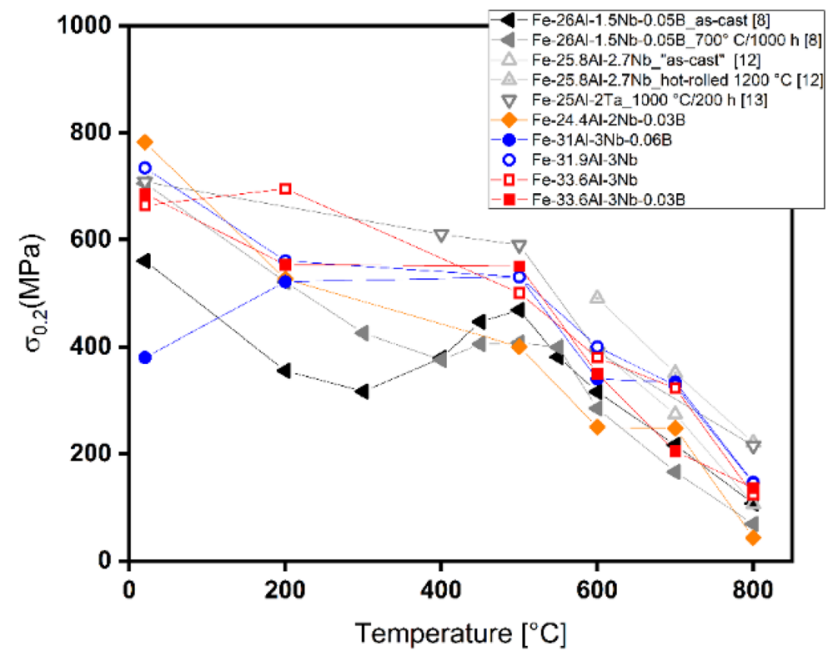

Fig. 7 Compressive yield stress $\sigma_{0.2}$ in dependence on temperature at a deformation rate of $10^{-4} \mathrm{~s}^{-1}$. Data are from heat-treated alloys $700{ }^{\circ} \mathrm{C} / 1000 \mathrm{~h}$. Data for "as-cast" and hot-rolled samples of an FeAl-Nb alloy with similar composition [12], for a B-doped alloy [8], and for an Fe-Al-Ta alloy [13] are shown for comparison

and "as-cast" alloy, both additionally annealed $1000{ }^{\circ} \mathrm{C} / 50 \mathrm{~h}$, with a similar composition [12], and an $\mathrm{Fe}-25 \mathrm{Al}-2 \mathrm{Ta}$ alloy [13]. For the $\mathrm{Fe}-\mathrm{Al}-\mathrm{Nb}(-\mathrm{B})$ alloys, no marked difference between individual alloys is noticed, showing that the B-doping has no effect on the yield strength. However, $\mathrm{Fe}-24.4 \mathrm{Al}-2 \mathrm{Nb}-0.03 \mathrm{~B}$ seems to have the lowest strength at high temperatures. This indicates that the obtained microstructure is still not efficient for strengthening, possibly because the Laves phase precipitates are already too coarse ( $2.5 \mu \mathrm{m}$ feret diameter) and distances between the particles are too large (about $6 \mu \mathrm{m}$ ) to act as barriers for dislocation motion. The observation that the alloys with higher Al contents are somewhat stronger at high temperatures, though their Laves phase precipitates are even coarser, may be attributed to the considerably higher $\mathrm{Nb}$ content in the $\mathrm{Fe}-\mathrm{Al}$ matrix (Table 1), resulting in higher solid solution hardening. The yield stress at high temperatures of the boron-doped alloys with 1.5 at.\% $\mathrm{Nb}$ (from [8]) with homogeneously distributed Laves phase precipitates in the matrix and at grain boundaries is similar to that of the present alloys. The as-cast alloy has a slightly higher yield stress, probably because of the higher amount of $\mathrm{Nb}$ in the matrix and, therefore a stronger solid solution hardening effect [8]. The rolled alloy with 25.8 at.\% $\mathrm{Al}$ and 2.7 at.\% $\mathrm{Nb}$ shows the highest yield stress at high temperatures due to homogeneously distributed Laves phase precipitates in addition to the higher $\mathrm{Nb}$ solubility in the matrix and therefore an increased solid solution hardening effect [12]. The Fe-25Al-2Ta alloy, shown for comparison, has been heat treated $1000{ }^{\circ} \mathrm{C} / 200 \mathrm{~h}$, resulting in a microstructure with Laves phase precipitates $(2.4 \mu \mathrm{m}$ diameter and $30 \mu \mathrm{m}$ inter-particle spacing) inside the $\mathrm{Fe}-\mathrm{Al}$

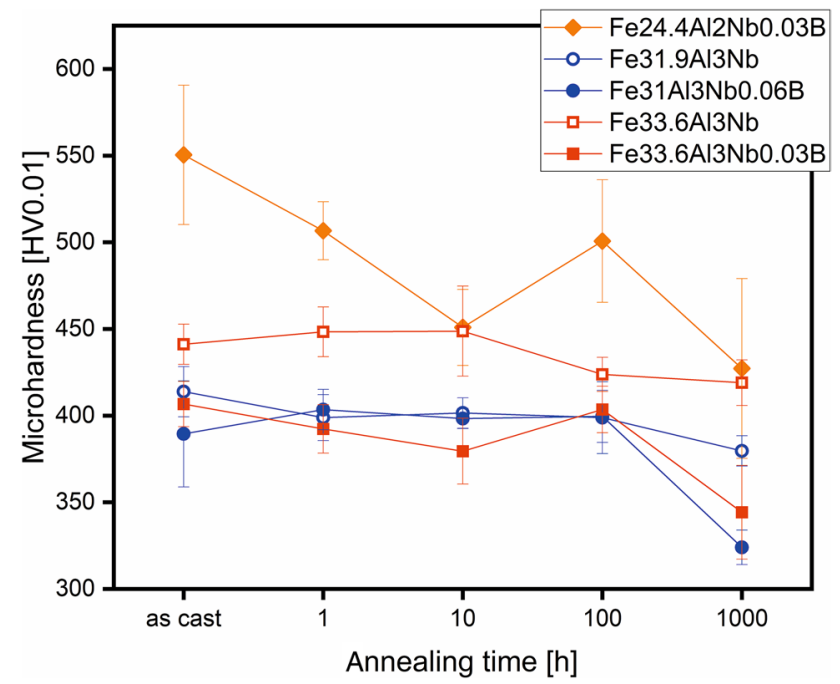

Fig. 8 Microhardness in dependence on the annealing time for different compositions

matrix and at the grain boundaries, which is comparable to the present ones [12]. The compressive yield stress is about the same as for the present alloys, though possibly a little bit higher at $800^{\circ} \mathrm{C}$.

The microhardness of the $\mathrm{Fe}-\mathrm{Al}$ matrix in dependence on the aging time at $700{ }^{\circ} \mathrm{C}$ is shown in Fig. 8. For the alloy $\mathrm{Fe}-24.4 \mathrm{Al}-2 \mathrm{Nb}-0.03 \mathrm{~B}$, the microhardness is measured in the matrix containing Heusler phase precipitates after $1 \mathrm{~h}$ heat treatment and increasing fraction of Laves phase precipitates after $10 \mathrm{~h}$ heat treatment. In view of the large scatter of the data any detailed analysis seems speculative. Again, no significant influence of B on the microhardness was noted.

\section{Conclusions}

Microstructure analysis and phase characterization via EPMA and XRD indicate that in $\mathrm{Fe}-\mathrm{Al}-\mathrm{Nb}-\mathrm{B}$ alloys the formation of fine-scaled, homogeneously distributed Laves phase is preceded by the formation of the metastable Heusler phase. The Heusler phase forms in the alloy with about 24 at.\% $\mathrm{Al}$ and 2 at.\% $\mathrm{Nb}$ and doped with boron after $1 \mathrm{~h}$ of heat treatment and transforms into the stable Laves phase upon longer annealing. The Heusler-to-Laves phase transformation occurs faster than in the Fe-Al-Ta system. No significant influence of boron on the microstructure and the mechanical properties could be observed. The yield stress of $\mathrm{Fe}-\mathrm{Al}-\mathrm{Nb}$ alloys is in the same order of magnitude as for an $\mathrm{Fe}-\mathrm{Al}-\mathrm{Ta}$ alloy of comparable composition and microstructure. 
Acknowledgments The authors would like to thank Michael Kulse and Dennis Klapproth for alloy processing, Jürgen Wichert for heat treatments and Irina Wossack for EPMA measurements. Partial financial support by the Federal Ministry for Economic Affairs and Energy through grant $0324317 \mathrm{C}$ is gratefully acknowledged.

Funding Open Access funding enabled and organized by Projekt DEAL.

Data availability The datasets generated during and/or analyzed during the current study are available from the corresponding author on reasonable request.

\section{Compliance with ethical standards}

Conflict of interest On behalf of all authors, the corresponding author states that there is no conflict of interest.

Open Access This article is licensed under a Creative Commons Attribution 4.0 International License, which permits use, sharing, adaptation, distribution and reproduction in any medium or format, as long as you give appropriate credit to the original author(s) and the source, provide a link to the Creative Commons licence, and indicate if changes were made. The images or other third party material in this article are included in the article's Creative Commons licence, unless indicated otherwise in a credit line to the material. If material is not included in the article's Creative Commons licence and your intended use is not permitted by statutory regulation or exceeds the permitted use, you will need to obtain permission directly from the copyright holder. To view a copy of this licence, visit http://creativecommons.org/licenses/by/4.0/.
2. M. Palm, F. Stein, G. Dehm, Iron aluminides. Annu. Rev. Mater. Res. 49, 297-326 (2019)

3. P. Prokopčáková, M. Švec, M. Palm, Microstructural evolution and creep of Fe-Al alloys. Int. J. Mater. Res. 107, 396-405 (2016)

4. R. Krein, M. Palm, The influence of $\mathrm{Cr}$ and $\mathrm{B}$ additions on the mechanical properties and oxidation behaviour of L21-ordered $\mathrm{Fe}-\mathrm{Al}-\mathrm{Ti}$-based alloys at high temperatures. Acta Mater. 56, 2400-2405 (2008)

5. M. Palm, Fe-Al materials for structural applications at high temperatures: current research at MPIE. Int. J. Mater. Res. 100, 277-287 (2009)

6. D.G. Morris, M.A. Muñoz-Morris, The stress anomaly in FeAlFe3Al alloys. Intermetallics 13, 1269-1274 (2005)

7. D.M. Dimiduk et al., A structural study of ordered pre. Acta Metall. 36, 2947-2958 (1988)

8. S.A. Azmi et al., Microstructure and mechanical properties of $\mathrm{Fe}-\mathrm{Al}-\mathrm{Nb}-\mathrm{B}$ alloys. MRS Adv. 2, 1353-1359 (2017)

9. M. Palm, Phase equilibria in the Fe corner of the Fe-Al-Nb system between 800 and $1150^{\circ} \mathrm{C}$. J. Alloys Compd. 475, 173-177 (2009)

10. O. Prymak, F. Stein, Solidification and high-temperature phase equilibria in the $\mathrm{Fe}-\mathrm{Al}$-rich part of the $\mathrm{Fe}-\mathrm{Al}-\mathrm{Nb}$ system. Intermetallics 18, 1322-1326 (2010)

11. D.G. Morris et al., Strengthening at high temperatures by precipitates in Fe-Al-Nb alloys. Intermetallics 14, 1204-1207 (2006)

12. P. Kratochvíl et al., The effect of Nb addition on the microstructure and the high-temperature strength of $\mathrm{Fe} 3 \mathrm{Al}$ aluminide. Metall. Mater. Trans. A. 49, 1598-1603 (2018)

13. D.D. Risanti, G. Sauthoff, Strengthening of iron aluminide alloys by atomic ordering and Laves phase precipitation for high-temperature applications. Intermetallics 13, 1313-1321 (2005)

\section{References}

1. C.G. McKamey, Iron aluminides, in Physical Metallurgy and Processing of Intermetallic Compounds. ed. by N.S. Stoloff, V.K. Sikka (Chapman Hall, New York, 1996), pp. 351-391 